\title{
Temperature mediates the impact of non-native rainbow trout on native freshwater fishes in South Africa's Cape Fold Ecoregion
}

\author{
Jeremy M. Shelton $(\mathbb{D} \cdot$ Olaf L. F. Weyl $\mathbb{B} \cdot$ Karen J. Esler $(\mathbb{D} \cdot$ Bruce R. Paxton • \\ N. Dean Impson • Helen F. Dallas
}

Received: 11 December 2017/Accepted: 27 April 2018/Published online: 9 May 2018

(C) Springer International Publishing AG, part of Springer Nature 2018

\begin{abstract}
Introduced rainbow trout Oncorhynchus mykiss have invaded many headwater streams in South Africa's Cape Fold Ecoregion (CFE) and pose arguably the greatest threat to several species of threatened native fishes. Trout impacts in these systems appear to be density-dependent; we hypothesized that temperature is a key factor determining trout density and corresponding impacts on native fishes. We took advantage of natural spatial and temporal thermal heterogeneity in two CFE headwater streams to investigate the influence of temperature and other environmental factors on trout density and impacts on native fish assemblages. Temperature
\end{abstract}

Electronic supplementary material The online version of this article (https://doi.org/10.1007/s10530-018-1747-7) contains supplementary material, which is available to authorized users.

J. M. Shelton $(\bowtie) \cdot$ B. R. Paxton · H. F. Dallas

Freshwater Research Centre, Office 23, Imhoff Farm,

Kommetjie, Cape Town, South Africa

e-mail: jeremy@frcsa.org.za

J. M. Shelton · K. J. Esler

Department of Conservation Ecology and Entomology,

Centre for Invasion Biology, Stellenbosch University,

Stellenbosch, South Africa

J. M. Shelton · O. L. F. Weyl

DST/NRF Research Chair in Inland Fisheries and

Freshwater Ecology, South African Institute for Aquatic

Biodiversity, Grahamstown, South Africa limited trout density (negative relationship) during summer surveys (hottest months), but not during spring and autumn (cooler months). During summer, the highest trout densities were recorded at sites that remained relatively cool (7-day moving average of the daily maximum temperature $\left(\operatorname{Max}_{-} 7\right)<27{ }^{\circ} \mathrm{C}$ ), while trout were generally absent from relatively warm sites (Max_7 $>27{ }^{\circ} \mathrm{C}$ ). Native fish density was best explained by trout density (inverse relationship) during summer, but by other environmental variables such as habitat complexity and current flow velocity during autumn and spring. Trout distributions expand during cooler seasons when thermal heterogeneity and maximum temperatures are relatively low, but contract into thermal refugia (habitat patches that remain relatively cool) as temperatures and thermal heterogeneity increase over summer, leaving warmer habitat patches vacant and able to function as predation

O. L. F. Weyl

Centre for Invasion Biology, South African Institute for Aquatic Biodiversity, Grahamstown, South Africa

N. D. Impson

CapeNature Scientific Services, Stellenbosch, South

Africa

H. F. Dallas

Nelson Mandela Metropolitan University, Port Elizabeth, South Africa 
refugia for native fish. We hypothesize that climate warming could reduce trout density and distribution, and associated impacts on native fish, in CFE headwater streams, but may increase the potential for invasions by other warm-adapted non-native predatory fish already established in downstream river reaches in the region.

Keywords Climate change - Invasive species . Endemic freshwater fish $\cdot$ Thermal refugia $\cdot$ Predation refugia

\section{Introduction}

Invasive species and climate change rank among the greatest threats facing the world's ecosystems over the next century, but are usually studied independently (Fey and Herren 2014). Studies of the interplay between these threats often reveal synergistic effects whereby the spread, establishment and impacts of introduced species are facilitated by climate change (Rahel and Olden 2008). How individual native and non-native species respond to climate change will depend on various factors including their evolutionary histories, behavioural and physiological adaptabilities, thermal preferences and tolerances (Cassie 2006). Responses will probably be strongly context-dependent, and different species might experience range shifts, expansions or contractions (Buisson and Grenouillet 2009). Freshwater ecosystems are especially vulnerable to the effects of climate change (Woodward et al. 2010) and accurate predictions about impacts on native species, non-native species and their interactions should be underpinned by a speciesspecific understanding of responses to anticipated climate change effects (Moyle et al. 2013; Dallas and Rivers-Moore 2014).

In the Cape Fold Ecoregion (CFE) of South Africa, non-native predatory fish introduced over the last two centuries for angling have had serious negative impacts on the abundance and distribution of several native fish species (Ellender et al. 2017). Many of these non-natives (e.g. the black basses Micropterus spp.) are adapted to relatively warm, low-lying habitats and have all but eliminated once abundant native fish populations from such areas (Ellender et al. 2017). Moreover, the middle and lower reaches of most rivers are moderately to severely degraded because of other impacts like water extraction, sedimentation and pollution (Shelton et al. 2017a). This has resulted in highly fragmented native fish populations and a common situation now is to find small, isolated pockets of native fish upstream in mountainous headwater reaches of streams (Chakona and Swartz 2012; de Moor and Day 2013). Thus, headwater habitats stand out as sanctuaries for populations of endemic freshwater fish against the backdrop of the region's largely-degraded riverscapes (Shelton et al. 2015).

Rainbow trout Oncorhynchus mykiss, a predatory salmonid introduced from the northern hemisphere in the 1890 s, is well adapted to environmental conditions in these cooler headwater reaches and may now pose the single greatest threat to the continued survival of small-bodied native fishes which are now almost entirely confined to headwater habitats (Ellender and Weyl 2014). A recent survey of fish populations in tributaries of the upper Breede River showed that rainbow trout can have a strong, negative predatory impact on native fish abundance and population structure, and that impacts appear to be densitydependent (Shelton et al. 2015). A sound understanding of the factors controlling rainbow trout density in these streams is thus needed to predict impacts of climate change on native fish.

Salmonid densities and distributions are regulated by a range of environmental factors including stream bed stability, stream size, water quality, temperature and flow regimes, other habitat factors correlated with stream gradient and channel geomorphology, and biotic resistance from native predators, competitors and parasites/diseases (see review by Fausch 2007). Rainbow trout is a stenothermic, cold-adapted species (optimal temperature $=11^{\circ} \mathrm{C}$, Clark et al. 2001) and thus is generally restricted to the cooler headwater reaches of CFE streams. Temperature may therefore be a key factor in regulating rainbow trout distributions and abundance in CFE headwater streams. Moreover, $\mathrm{a} \sim 2{ }^{\circ} \mathrm{C}$ increase in mean water temperature as predicted by Dallas and Rivers-Moore (2014) for CFE stream environments over the next 30-50 years may be expected to have a negative impact on rainbow trout populations in the region. On the other hand, data on thermal preferences and tolerances of the native small-bodied fish species within the genera Galaxias, Sandelia and 
Pseudobarbus are scarce. However, these fishes are known to occur in warmer downstream reaches of streams in cases where invasive predators are absent, suggesting that they may be better-adapted to warmer temperatures than are rainbow trout.

We hypothesize that temperature is a key variable in determining the density and distribution of rainbow trout and associated impacts on native fish populations in CFE headwater streams. Specifically, we predict that temperature is a key variable explaining spatiotemporal variation in rainbow trout density, and that a negative relationship exists between trout density and water temperature in CFE headwater streams. A second prediction is that temperature mediates the impact of rainbow trout on native fish abundance, with the strongest impacts on native fish resulting where water temperature remains relatively low, and weaker impacts expected where relatively high temperatures occur. We took advantage of the natural spatial and temporal thermal heterogeneity in CFE headwater streams to determine the influence of temperature on rainbow trout, native fish and interactions between them (sensu Petty et al. 2012). The results are then used to speculate on the consequences of climate warming for these (and other) native and non-native species and their interactions in the CFE.

\section{Methods}

Study area

This study was conducted in headwater streams of the Berg (upper Berg River and Assegaaibos River) and Breede (Amandel River) Rivers in the CFE (Fig. 1). These tributaries were selected because (1) they are not seriously influenced by human activities, (2) they exhibited high levels of spatio-temporal thermal heterogeneity and (3) they contain populations of native fishes and rainbow trout (but no other nonnative fish). The climate is Mediterranean with a mean annual rainfall of $\sim 800 \mathrm{~mm}$. Natural vegetation is predominantly Sandstone Fynbos, and riparian vegetation is dominated by broad-leaved woody species including perennial shrubs and small trees. The geology is dominated by hard, quartzitic sandstones of the Table Mountain group, and the streams flowing over this stratum are acidic, oligotrophic and low in dissolved solids (de Moor and Day 2013). Both streams are generally $<10 \mathrm{~m}$ wide, $<1 \mathrm{~m}$ deep and comprise sections of alternating pool, run and riffle habitats. In the Amandel River the native freshwater fish are the Breede River redfin Pseudobarbus burchelli (henceforth 'redfin'), the Cape kurper Sandelia capensis (henceforth 'kurper'), and the Cape galaxias Galaxias zebratus (henceforth 'galaxias), while S. capensis, G. zebratus and the Berg River redfin Pseudobarbus burgi (henceforth 'redfin') inhabit the upper Berg River. Rainbow trout (henceforth 'trout') was introduced to the Berg and Amandel rivers in the early 1900s for angling purposes and at now cooccurs with native fish in both rivers. In addition to trout, non-native predatory fish like black basses Micropterus spp. and sharptooth catfish Clarias gariepinus occur downstream of the study area in both the Berg (Clark et al. 2009) and Amandel (Shelton et al. 2017b) Rivers, where upstream invasion appears to be prevented by weirs which act as physical dispersal barriers.

\section{Data collection}

On a $\sim 3 \mathrm{~km}$ stretch of each river we selected sites that encompassed the broadest-possible range of environmental and thermal conditions in each stream. Sites comprised either pools or runs that were bound by riffles on their upstream and downstream ends, and were situated at least $100 \mathrm{~m}$ apart (Fig. 1). Water temperature loggers (Hobo TidbiT ${ }^{\circledR} \mathrm{v} 2$ ), programmed to record hourly temperatures, were installed in the deepest part of each site during February 2015 using a bracket and bolt to attach a steel cable to a large boulder expected not to move during winter high flows.

Fish populations were surveyed, and other relevant habitat variables measured, in May 2015 (autumn), October 2015 (spring), December 2015 (early summer) and February 2016 (late summer) (see Fig. 2). The two-pass snorkel survey method (Ellender et al. 2012) was employed to estimate the densities of all fish species present at each site. On completion of the fish surveys, a set of environmental variables of known importance to stream fish (based on McIntosh 2000), was measured (see Online Resource 1 for 


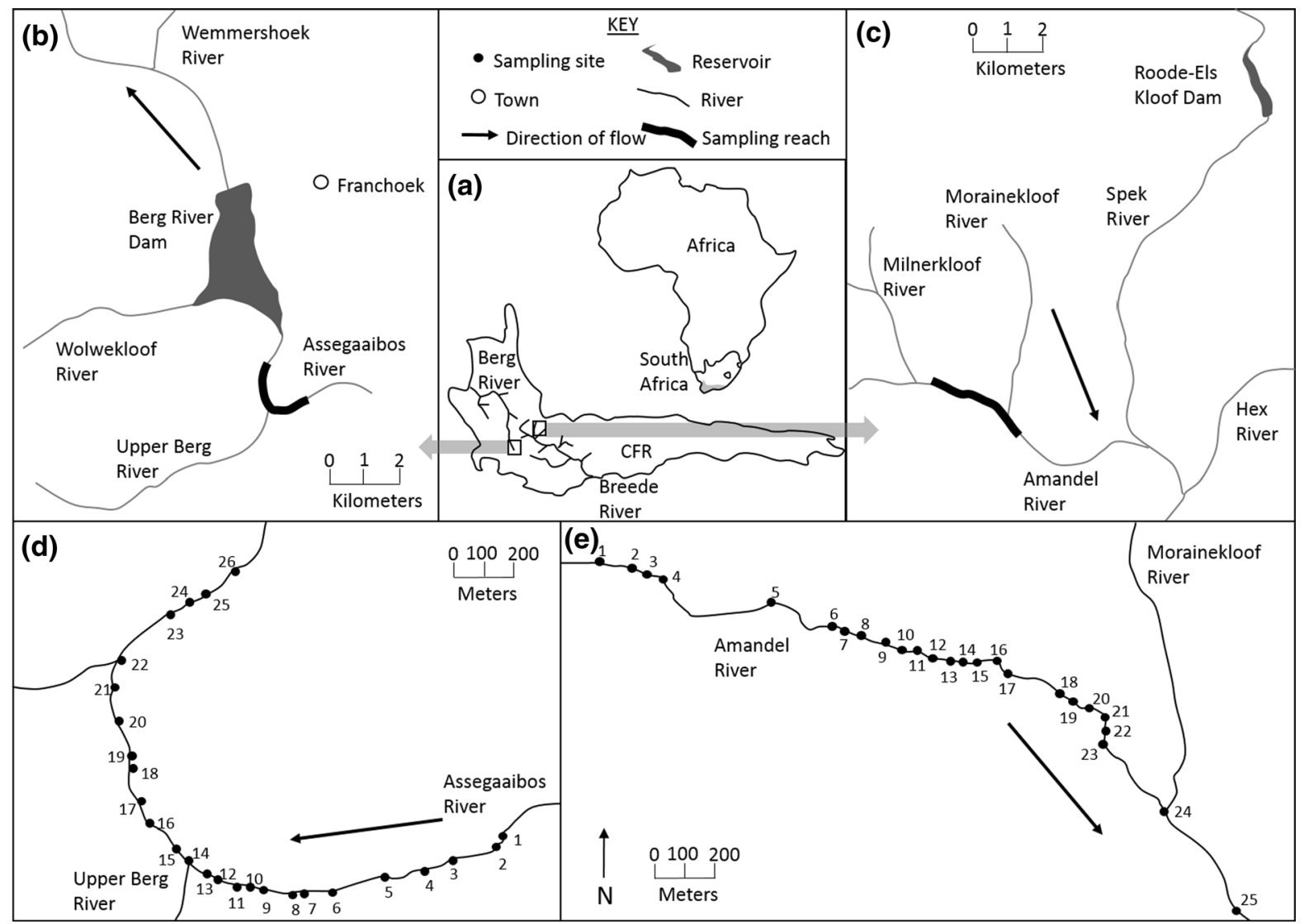

Fig. 1 Location of the Berg and Breede Rivers in the Cape Fold Ecoregion (a), study reaches and sampling sites on the upper Berg (b, d) and Amandel (c, e) Rivers

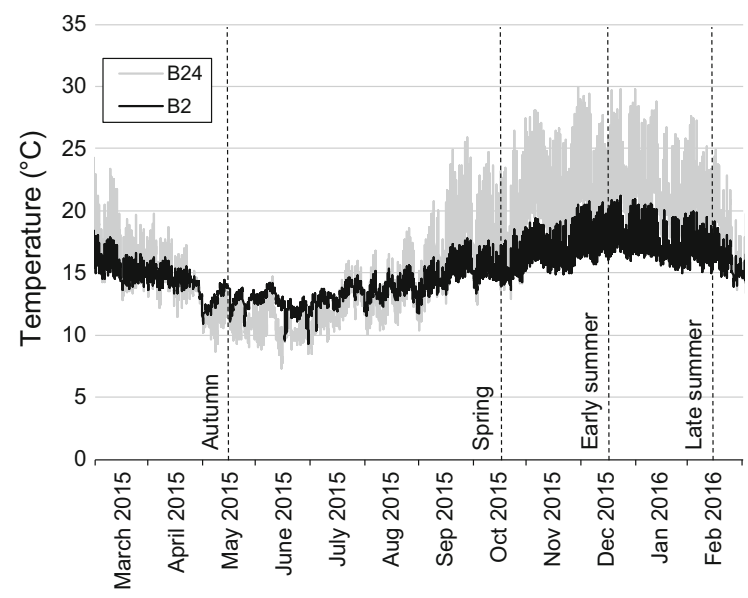

Fig. 2 Example of thermographs from two sites on the Berg River that experience different maximum temperatures (Max_7) during summer. Site B24 is close to the downstream end of the study area (Fig. 3) and experienced relatively high summer temperatures, while site B2 further upstream remained relatively cool throughout the year abbreviations, units and a brief description of each habitat parameter assessed). Site length, and the wetted channel width at three evenly-spaced intervals were measured $(\mathrm{cm})$ along the length of the site with a tape measure. We then measured water depth $(\mathrm{cm})$, substrate length $(\mathrm{mm})$, flow $(\mathrm{m} / \mathrm{s})$, canopy cover $(\%)$ and instream cover (\%) at three equidistant points along each width transect. Maximum depth (max depth) was measured in the deepest location at each site and average flow of the water column was measured at each point with a digital flow meter. The percentages of canopy and instream (proportion of stream bed with physical features that could potentially conceal fish) cover were estimated visually at each site. Dissolved oxygen (DO: $\mathrm{mg} / \mathrm{l}$ ) was recorded at three random locations within each site. The spatial coordinates of each site were recorded with a GPS, and site elevation was ascertained from digitized topographic maps. 

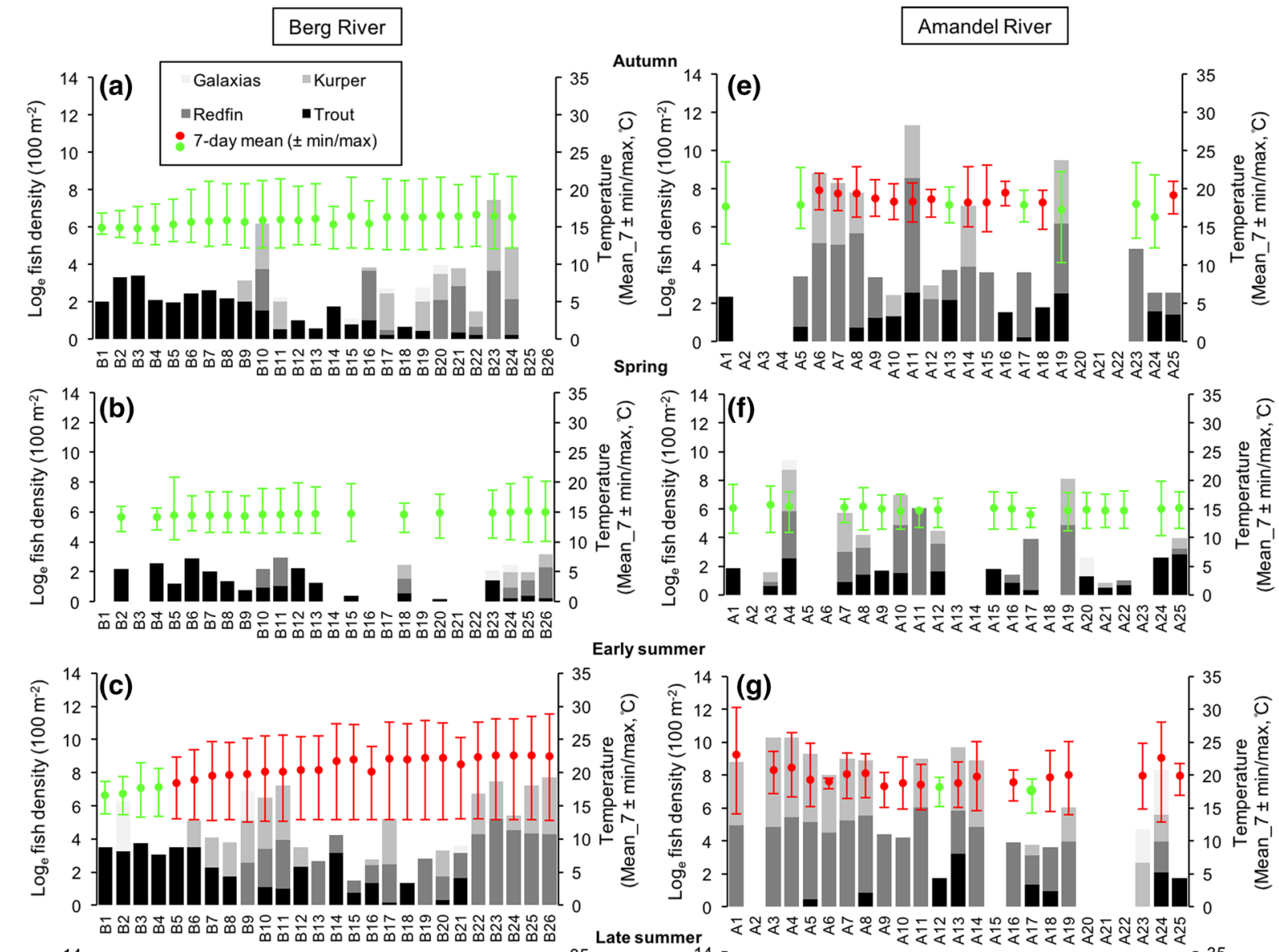

arly summer

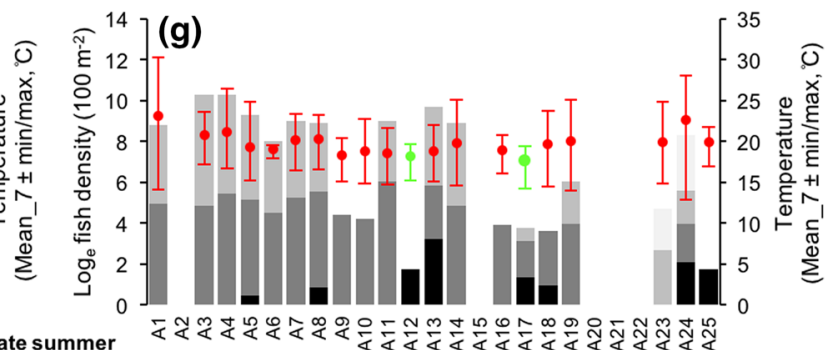

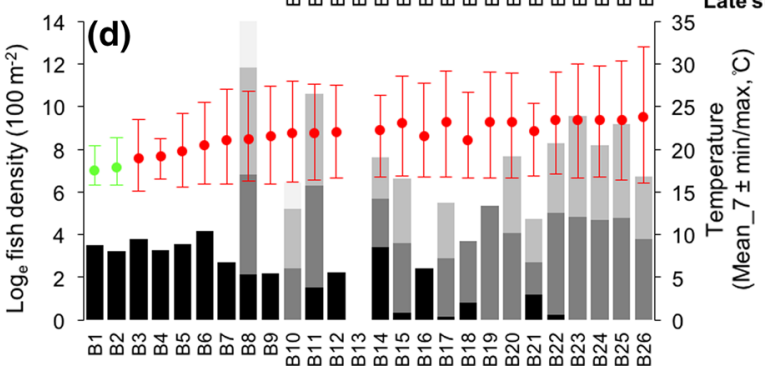

Fig. 3 Fish densities $\left(100 \mathrm{~m}^{-2}\right)$ and temperature (Mean_7 \pm max and min temperature, ${ }^{\circ} \mathrm{C}$ ) at the 26 sampling sites on the Berg River, and 25 sites on the Amandel River during May 2015 (autumn), October 2015 (spring), December 2015 (early summer) and February 2016 (late summer). Red data points

Data analysis

The maximum weekly allowable temperature (MWAT) is commonly-used to measure the influence of temperature on fish distributions and physiologies in streams (Dallas 2008), and indicates a species' chronic stress threshold (Ellender et al. 2016). The

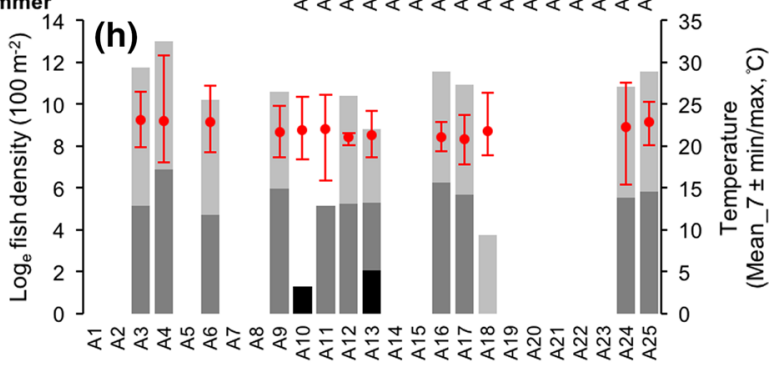

indicate occasions where the chronic stress threshold (MWAT) for rainbow trout (sensu Brungs and Jones 1977) was exceeded, while green data points indicate sites that remained below the chronic stress threshold for that season. Explanations of sites with no data can be found in Table S1

metric integrates the optimum temperature (OT) and incipient lethal upper temperature (ILUT) for a species as follows:

$\mathrm{MWAT}=\mathrm{OT}+\frac{(\mathrm{ILUT}-\mathrm{OT})}{3}$ 
For rainbow trout, $18.2{ }^{\circ} \mathrm{C}$ is a conservative estimate of the chronic stress threshold value $\left(\mathrm{OT}=14.0^{\circ} \mathrm{C}\right.$; ILUT $\left.=26.5^{\circ} \mathrm{C}\right)($ Brungs and Jones 1977), which can be related to the average daily mean temperature of the seven warmest consecutive days (Mean_7) over the period of interest (sensu Rivers-Moore et al. 2013a, i.e. the 7-day moving average of the daily mean temperature). Thus, Mean_7 values were estimated for each site in the Berg and Amandel Rivers, using temperature data recorded from the month preceding the fish surveys, to assess the seasonal suitability of each site for trout. These values (as well as the minimum and maximum temperature for that month) were then overlaid onto fish density estimates for each site to gauge how well trout distributions in the study streams conformed to the chronic stress threshold (Ellender et al. 2016).

Relationships between trout density and thermal and environmental predictors for each river and season were investigated using distance-based linear models (DISTLM, Anderson et al. 2008). This approach allowed us to evaluate the seasonal importance of temperature versus other environmental variables on trout and native fish densities in each system (sensu Buisson et al. 2008). DISTLM is a non-parametric multivariate multiple regression technique for analysing and modelling the relationship between one or more response variables (as described by a resemblance matrix) and a set of biotic and/or abiotic predictor variables (Anderson et al. 2008).

The mean depth, substrate particle length, flow velocity, canopy cover and instream cover were estimated from the nine measurements taken along transects at each site. Maximum depth, elevation and site width estimates were based on a single measurement, and mean dissolved oxygen concentration from the three measurements taken at each site. The hourly temperature data for the month preceding each survey were converted into seven thermal metrics including maximum temperature, minimum temperature, mean temperature, the standard deviation of the mean temperature, temperature range, a 7-day moving average of the daily mean temperature (Mean_7) and a 7-day moving average of the daily maximum temperature (Max_7). The choice of temperature metrics included in this analysis was based on the thermal characteristics of rivers considered to have the greatest influence on aquatic biota (Rivers-Moore et al. 2013b; Dallas and Rivers-Moore 2014). In total, this resulted in a set of nine habitat, and seven thermal, parameters which were used as predictors of trout and native fish densities for each river and season (see Online Resource 1). Trout density was included as an additional predictor variable in models for native fish densities.

Environmental and thermal predictors were checked for multicollinearity, and in cases where two or more variables were highly correlated (Pearson's correlation coefficient $r$ exceeded 0.70 ), only one variable was retained for further analysis (Anderson et al. 2008; Budaev 2010) (see Online Resource 2). The distributions of the refined set of predictor variables, as well as the response variables 'trout density' or 'native fish density', were then examined using draftsman plots and variables with skewed distributions were transformed $[\ln (x+1)$ or arcsinsquare root for $\%$ parameters]. Resemblance matrices were calculated using Euclidian distance, which is appropriate for models assessing the influence of environmental factors on a single response variable (Anderson et al. 2008).

A step-wise procedure with the $\mathrm{AIC}_{\mathrm{c}}$ selection criterion (Akaike's Selection Criterion for small sample sizes, Burnham and Anderson 2002) was used to identify the combination of predictors that produced the most parsimonious model explaining the variation in trout and native fish densities among sites for each river and season. Simple linear regressions were then used to investigate relationships between response variables and any selected predictors explaining a significant proportion of variation in the final model. No models were built for galaxias given that they were absent from $\sim 95 \%$ of the sites surveyed, and their low densities where present (Fig. 3).

Finally, for the Berg River we plotted fish densities at each site against temperature (Max_7) for sites with trout only, native fish only and trout and native fish together so as to visualise patterns in fish abundance and assemblage composition in relation to temperature. The assumption being that sites with native fish only are unsuitable for trout, that sites where trout cooccur with native fish represent areas less suitable for trout where their impact on native fish is relatively weak, and sites with trout only represent habitats that are optimal for trout where their impact is relatively strong leading to the apparent disappearance of native fish. 
All univariate analyses were carried out with SPSS 22.0 (SPSS 2014), and multivariate analyses were performed using PRIMER-E (Clarke and Gorley 2006) with the add-on package PERMANOVA+ (Anderson et al. 2008).

\section{Results}

The number of sites sampled varied among seasons because of instances where temperature loggers were lost, where loggers were only installed after the first survey in May 2016, where loggers became exposed to air, or where sampling sites dried up altogether (Online Resource 3). In the Berg River, 24 sites were sampled in autumn, 18 in spring, 26 in early summer and 25 in late summer. In the Amandel River, 20 sites were sampled in autumn, 18 in spring, 20 in early summer and 13 in late summer. Several of the sampling sites on the Amandel River dried up during summer including four in early summer and a further six in late summer.

Thermal characteristics of sampling sites and exceedance of the chronic stress threshold for rainbow trout

Thermal heterogeneity was evident within both systems, both among seasons, and among sites within a season (Figs. 2, 3). The thermal heterogeneity between sites is illustrated by the comparison of the thermal profiles at the Berg River sites B2 (low variability) and B24 (high variability) in Fig. 2. In the Berg River, water temperature ranged from an instantaneous high of $32.0^{\circ} \mathrm{C}$ (site B26) in late summer to a low of $10.0{ }^{\circ} \mathrm{C}$ (site B25) in spring. In the Amandel River water temperature ranged from $30.9{ }^{\circ} \mathrm{C}$ (site A4) in late summer to $10.4{ }^{\circ} \mathrm{C}$ (site A24) in spring. In both rivers water temperatures only exceeded $25{ }^{\circ} \mathrm{C}$ for $<10 \%$ of the time over an annual cycle, and $<$ $35 \%$ over the hottest month, January.

In the Berg River, Mean_7 values ranged from 17.6 to $23.8^{\circ} \mathrm{C}$ in late summer to $14.1-15.1{ }^{\circ} \mathrm{C}$ in spring. In the Amandel River the Mean_7 values ranged from 20.8 to $23.1{ }^{\circ} \mathrm{C}$ in late summer to $14.9-16.8{ }^{\circ} \mathrm{C}$ in spring. Thermal heterogeneity among sites within systems was most pronounced during the summer surveys. In the Berg River, Mean_7 values fell below the chronic stress threshold for trout $\left(18.2{ }^{\circ} \mathrm{C}\right)$ at all sites during the autumn (Fig. 3a) and spring (Fig. 3b) surveys. In early summer, the threshold was exceeded at all but the upper-most four sites (chronic stress threshold exceeded at $85 \%$ of sites, Fig. 3c), and by late summer only the top two sites remained below the threshold (chronic stress threshold exceeded at $92 \%$ of sites, Fig. 3d). In the Amandel River, $63 \%$ of sites exceeded the chronic stress threshold in Autumn (Fig. 3e), but no sites exceeded it during spring (Fig. 3f). Only two of the sites fell below the threshold during early summer (chronic stress threshold exceeded at $95 \%$ of sites, Fig. 3g), and by late summer the threshold had been exceeded at all sampling sites (Fig. 3h).

Unexpectedly, trout, while present at most of the sites where the threshold was not exceeded (Berg River $=96 \%$ of sites, Amandel River $=93 \%$ of sites $)$, was also present at many of the sites where the threshold was exceeded (Berg River $=64 \%$ of sites, Amandel River $=35 \%$ of sites). In the Berg River, the highest trout density recorded was 68.8 fish $100 \mathrm{~m}^{-2}$, and trout density remained relatively high (generally above 3 fish $100 \mathrm{~m}^{-2}$ ) at the uppermost sites (B1-B9) during all seasons (Fig. 3). Trout were present at $92 \%$ of sites during autumn and $100 \%$ of sites during spring, but only recorded at 60 and $72 \%$ of the sites during early and late summer respectively (Fig. 3). In the Amandel River, the highest trout density was 23.8 fish $100 \mathrm{~m}^{-2}$, but trout densities at sites in this system rarely exceeded 5 fish $100 \mathrm{~m}^{-2}$. Trout were present at $65 \%$ of sites during autumn and $89 \%$ of sites during spring, but only recorded at 40 and $15 \%$ of the sites during early and late summer respectively (Fig. 3).

Influence of temperature and habitat on trout density

\section{Berg River}

The models for trout density during autumn and spring explained 87 and $68 \%$ of the variation in trout density among sites respectively (Table 1). Both models featured elevation (negatively correlated with mean width, positively correlated with dissolved oxygen concentration) as the top predictor, and trout density was highest at sites with relatively high elevations, narrow channels and high dissolved oxygen concentrations during both seasons. Elevation accounted for a significant proportion of the variation in trout density 
Table 1 Test statistics for distance-based linear model (DISTLM) analysis investigating relationships between trout density and a set of predictor variables including nine habitat, and seven thermal, predictors for autumn, spring, early summer and late summer in the Berg and Amandel Rivers

\begin{tabular}{|c|c|c|c|c|c|c|c|}
\hline Variable & $\mathrm{AIC}_{c}$ & SS & $F$ & $P$ & Variation $(\%)$ & Cumulative variation $(\%)$ & Residual ( $d f$ ) \\
\hline \multicolumn{8}{|l|}{ Berg River } \\
\hline \multicolumn{8}{|l|}{ Autumn } \\
\hline +Elevation & -28.5 & 19.02 & 69.15 & $<0.001$ & 0.76 & 0.76 & 22 \\
\hline+ Mean flow velocity ${ }^{\mathrm{a}}$ & -32.87 & 1.53 & 7.11 & 0.02 & 0.06 & 0.82 & 21 \\
\hline+ Mean substrate length & -38.42 & 1.34 & 8.45 & 0.007 & 0.05 & 0.87 & 20 \\
\hline \multicolumn{8}{|l|}{ Spring } \\
\hline +Elevation & -13.93 & 6.2 & 15.6 & $<0.001$ & 0.49 & 0.49 & 16 \\
\hline -Mean_7 & -14.66 & 1.17 & 3.38 & 0.091 & 0.09 & 0.59 & 15 \\
\hline+ Mean flow velocity ${ }^{\mathrm{a}}$ & -16.05 & 1.21 & 4.23 & 0.07 & 0.1 & 0.68 & 14 \\
\hline \multicolumn{8}{|l|}{ Early summer } \\
\hline -Max_7 & -7.16 & 32.46 & 46.96 & $<0.001$ & 0.66 & 0.66 & 24 \\
\hline+ Max depth ${ }^{\mathrm{a}}$ & -10.23 & 3.24 & 5.57 & 0.018 & 0.07 & 0.73 & 23 \\
\hline \multicolumn{8}{|l|}{ Late summer } \\
\hline -Max_7 & -1.37 & 35.36 & 41.22 & $<0.001$ & 0.64 & 0.64 & 23 \\
\hline+ Dissolved oxygen $^{\mathrm{a}}$ & -6.12 & 5.02 & 7.51 & 0.019 & 0.09 & 0.73 & 22 \\
\hline \multicolumn{8}{|l|}{ Amandel River } \\
\hline \multicolumn{8}{|l|}{ Autumn } \\
\hline -Max_7 & -2.97 & 3.5 & 4.63 & 0.038 & 0.2 & 0.2 & 18 \\
\hline -Mean flow velocity & -4.75 & 2.79 & 4.37 & 0.028 & 0.16 & 0.37 & 17 \\
\hline -Mean width & -5.1 & 1.75 & 3.07 & 0.102 & 0.1 & 0.47 & 16 \\
\hline \multicolumn{8}{|l|}{ Spring } \\
\hline +Max_7 & -3.64 & 2.53 & 3.59 & 0.07 & 0.18 & 0.18 & 16 \\
\hline+ Max depth ${ }^{\mathrm{a}}$ & -8.89 & 4.11 & 8.61 & 0.007 & 0.3 & 0.48 & 15 \\
\hline \multicolumn{8}{|l|}{ Early summer } \\
\hline- Max_7 & -4.46 & 4.04 & 5.75 & 0.022 & 0.24 & 0.24 & 18 \\
\hline+ Max depth ${ }^{\mathrm{a}}$ & -4.77 & 1.82 & 2.85 & 0.095 & 0.11 & 0.35 & 17 \\
\hline
\end{tabular}

A step-wise procedure with Akaike's Selection Criterion for small sample sizes $\left(\mathrm{AIC}_{c}\right)$ was used to identify the combination of predictors that produced the most parsimonious model for each predictor variable. A "+" preceding a predictor indicates that the direction of relationship between that predictor and the response variable is positive, and "- " indicates that it is negative

${ }^{a}$ Indicates that a variable was $\ln (\mathrm{x}+1)$-transformed

Bold value indicates a significant difference at $\alpha=0.05$

during both the autumn $(P<0.001,76 \%$ variation $)$ and spring $(P<0.001 ; 49 \%$ variation $)$ surveys. Current velocity $(P=0.020)$ and mean substrate length $(P=0.007)$ also explained a significant, although relatively small $(<10 \%)$, proportion of the variation in trout density during autumn, and trout density was generally highest at sites with relatively large mean substrate sizes and fast flows. Current velocity and temperature (Mean_7) featured alongside elevation in the final model for trout during spring, although neither predictor explained a significant proportion of the variation in trout density among sites. The models for trout density in early and late summer both explained $73 \%$ of the total variation in trout density among sites (Table 1). Temperature (Max_7) was the top predictor in the models for both early $(P<0.001$; $66 \%$ variation $)$ and late $(P<0.001 ; 64 \%$ variation $)$ summer, and was negatively related to trout density, indicating that trout density was consistently highest at the cooler sites (Fig. 4a). For both seasons Max_7 was correlated with, and represented, other thermal metrics including maximum, mean, standard deviation, range 


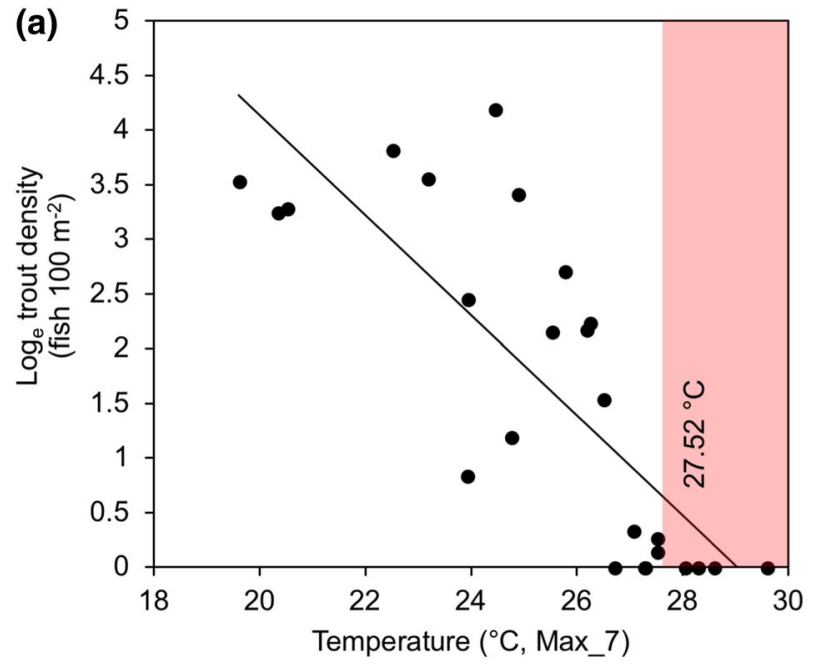

Fig. 4 Linear relationships between (a) $\log _{\mathrm{e}}$ trout density (fish $\left.100 \mathrm{~m}^{-2}\right)$ and temperature $\left({ }^{\circ} \mathrm{C}, \mathrm{Max}_{-} 7\right)$ and (b) between $\log _{\mathrm{e}}$ native fish density (fish $100 \mathrm{~m}^{-2}$ ) on the Berg River during late

and Mean_7 temperatures in the models. In addition to temperature, maximum depth $(P=0.018,18 \%$ variation) and dissolved oxygen ( $P=0.019,9 \%$ variation $)$ were positively related to trout density, and explained lower, but still significant proportions of the variation in trout density among sites during early and late summer respectively.

\section{Amandel River}

The models for trout density during autumn, spring and early summer explained 47,48 and $35 \%$ of the variation in trout density among sites respectively (Table 1). No model was built for late summer in the Amandel River because only 13 sites were sampled and because only two of those sites contained trout (Fig. 3). Temperature (Max_7) was the top predictor of trout density, and explained a significant proportion of the variation in trout density during autumn $(P=0.038$, variation $20 \%)$ and late summer $(P=0.022, \quad 47 \%$ variation $)$ but not spring ( $P=0.070,18 \%$ variation) (Table 1$)$. In the models for all seasons, Max_7 was correlated with, and represented, other thermal metrics including maximum, mean, standard deviation, range and Mean_7 temperatures in the models. Other predictors featuring in the autumn model included current velocity $(P=0.028, \quad 16 \%$ variation $)$ and stream width $(P=0.102,10 \%)$. Both predictors were negatively

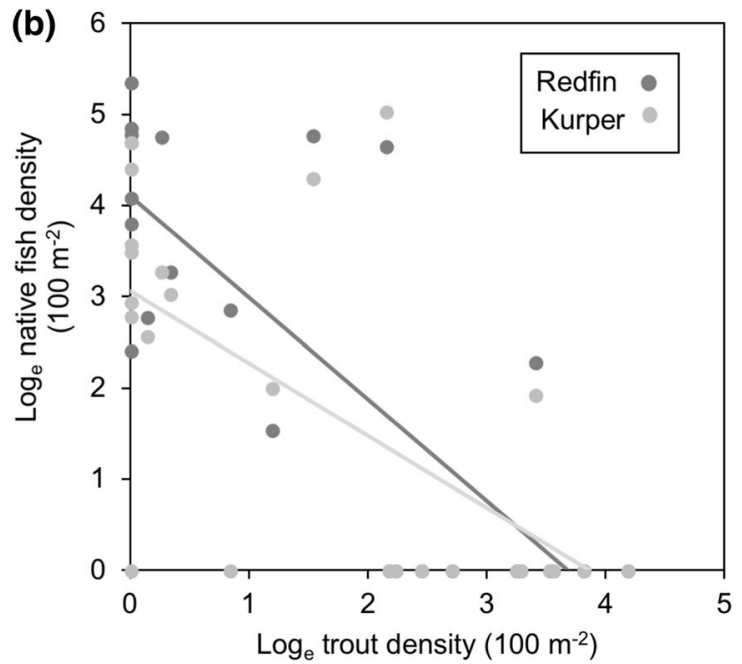

summer. The red shading indicates the highest value of Max_7 where trout was recorded

related to trout density indicating that trout densities tended to be highest at narrow sites with low current velocities. Maximum depth (correlated with mean depth) featured alongside temperature in the models for spring and early summer, and explained a significant proportion of the variation in trout density during spring $(P=0.007$, variation $30 \%)$, but not early summer $(P=0.095,11 \%$ variation $)$. Trout density was positively related to depth during spring indicating that trout density was consistently higher at deeper sites during this season.

Influence of trout, habitat and temperature on native fish density

\section{Berg River}

The models for redfin explained 34 and $23 \%$ of the total variation in redfin density during autumn and spring respectively (Table 2), and elevation (negatively correlated with mean stream width, positively correlated with dissolved oxygen concentration) was the only predictor featuring in these models. Elevation explained a significant proportion of the variation in redfin density during both seasons (autumn: $P=0.004$; spring: $P=0.044,23 \%$ variation), and redfin density was consistently higher at lower-lying sites (Fig. 3a, b) with relatively broad channel widths and low dissolved oxygen concentrations. 
Table 2 Test statistics for distance-based linear model (DISTLM) analysis investigating relationships between native fish (redfin and kurper) densities and a set of predictor variables including nine habitat, and seven thermal, predictors for autumn, spring, early summer and late summer in the Berg and Amandel Rivers

\begin{tabular}{|c|c|c|c|c|c|c|c|}
\hline Variable & $\mathrm{AIC}_{c}$ & SS & $F$ & $P$ & Variation $(\%)$ & Cumulative variation (\%) & Residual $(d f)$ \\
\hline \multicolumn{8}{|l|}{ Berg River } \\
\hline \multicolumn{8}{|l|}{ Redfin } \\
\hline \multicolumn{8}{|l|}{ Autumn } \\
\hline -Elevation & -0.66 & 10.13 & 11.55 & 0.004 & 0.34 & 0.34 & 22 \\
\hline \multicolumn{8}{|l|}{ Spring } \\
\hline -Elevation & -13.97 & 1.86 & 4.69 & 0.044 & 0.23 & 0.23 & 16 \\
\hline \multicolumn{8}{|l|}{ Early summer } \\
\hline- Trout density ${ }^{\mathrm{a}}$ & 4.37 & 50.75 & 47.11 & $<0.001$ & 0.66 & 0.66 & 24 \\
\hline \multicolumn{8}{|l|}{ Late summer } \\
\hline- Trout density $^{\mathrm{a}}$ & 14.73 & 68.2 & 41.75 & $<0.001$ & 0.64 & 0.64 & 23 \\
\hline \multicolumn{8}{|l|}{ Kurper } \\
\hline \multicolumn{8}{|l|}{ Autumn } \\
\hline -Elevation & -3.86 & 10.62 & 13.83 & 0.002 & 0.39 & 0.39 & 22 \\
\hline- Max depth ${ }^{\mathrm{a}}$ & -6.72 & 3.45 & 5.4 & 0.029 & 0.13 & 0.51 & 21 \\
\hline \multicolumn{8}{|l|}{ Spring } \\
\hline -Elevation & -41.98 & 1.04 & 12.48 & 0.005 & 0.44 & 0.44 & 16 \\
\hline+ Canopy cover ${ }^{\mathrm{b}}$ & -44 & 0.32 & 4.73 & 0.044 & 0.13 & 0.57 & 15 \\
\hline \multicolumn{8}{|l|}{ Early summer } \\
\hline- Trout density $^{\mathrm{a}}$ & 8.44 & 10.36 & 8.22 & 0.016 & 0.26 & 0.26 & 24 \\
\hline \multicolumn{8}{|l|}{ Late summer } \\
\hline- Trout density $^{\mathrm{a}}$ & 20.45 & 36.09 & 17.58 & 0.002 & 0.43 & 0.43 & 23 \\
\hline \multicolumn{8}{|l|}{ Amandel River } \\
\hline \multicolumn{8}{|l|}{ Redfin } \\
\hline \multicolumn{8}{|l|}{ Autumn } \\
\hline+ Instream cover & 25.81 & 21.47 & 6.73 & 0.025 & 0.27 & 0.27 & 18 \\
\hline- Trout density ${ }^{\mathrm{a}}$ & 19.78 & 20.47 & 9.42 & 0.013 & 0.26 & 0.53 & 17 \\
\hline -Mean flow velocity ${ }^{a}$ & 16.54 & 10.14 & 6.05 & 0.042 & 0.13 & 0.66 & 16 \\
\hline \multicolumn{8}{|l|}{ Spring } \\
\hline+ Instream cover & 17.66 & 26.39 & 11.49 & 0.006 & 0.42 & 0.42 & 16 \\
\hline- Max_7 & 9.54 & 16.84 & 12.68 & 0.002 & 0.27 & 0.68 & 15 \\
\hline +Canopy cover & 7.55 & 5.13 & 4.85 & 0.041 & 0.08 & 0.77 & 14 \\
\hline -Mean flow velocity & 4.6 & 4.7 & 6.04 & $\mathbf{0 . 0 3 3}$ & 0.07 & 0.84 & 13 \\
\hline \multicolumn{8}{|l|}{ Early summer } \\
\hline +Elevation & 26.83 & 17.48 & 5.2 & 0.042 & 0.22 & 0.22 & 18 \\
\hline+ Max depth ${ }^{\mathrm{a}}$ & 19.48 & 24.05 & 11.23 & 0.01 & 0.31 & 0.53 & 17 \\
\hline- Trout density $^{\mathrm{a}}$ & 18.42 & 6.94 & 3.77 & 0.066 & 0.09 & 0.62 & 16 \\
\hline \multicolumn{8}{|l|}{ Late Summer } \\
\hline- Trout density $^{\mathrm{a}}$ & 20.81 & 15.37 & 3.92 & 0.061 & 0.26 & 0.26 & 11 \\
\hline \multicolumn{8}{|l|}{ Kurper } \\
\hline \multicolumn{8}{|l|}{ Autumn } \\
\hline+ Instream cover & 13.41 & 7.76 & 4.52 & 0.056 & 0.2 & 0.2 & 18 \\
\hline -Mean flow velocity & 13.14 & 4.4 & 2.82 & 0.11 & 0.11 & 0.31 & 17 \\
\hline Spring & & & & & & & \\
\hline
\end{tabular}


Table 2 continued

\begin{tabular}{lccccccc}
\hline Variable & $\mathrm{AIC}_{c}$ & $\mathrm{SS}$ & $F$ & $P$ & Variation $(\%)$ & Cumulative variation $(\%)$ & Residual $(d f)$ \\
\hline $\begin{array}{l}\text { +Instream cover } \\
\text { Early summer }\end{array}$ & 3.91 & 5.1 & 4.76 & $\mathbf{0 . 0 4 9}$ & 0.23 & 0.23 & 16 \\
$\quad$-Dissolved oxygen & 22.74 & 12.98 & 4.74 & $\mathbf{0 . 0 1 7}$ & 0.21 & 0.21 & 18 \\
$\quad$ +Max_7 & 20.49 & 10.99 & 4.88 & $\mathbf{0 . 0 4 1}$ & 0.18 & 0.39 & 17 \\
$\quad$ - Min temp & 15.2 & 13.2 & 8.42 & $\mathbf{0 . 0 1 7}$ & 0.21 & 0.6 & 16 \\
$\quad \begin{array}{l}\text { Late summer } \\
\quad \text {-Trout density }\end{array}$ & 20.65 & 11.03 & 2.84 & $\mathbf{0 . 1 4 3}$ & 0.21 & 0.21 & 11 \\
\hline
\end{tabular}

A step-wise procedure with Akaike's Selection Criterion for small sample sizes $\left(\mathrm{AIC}_{c}\right)$ was used to identify the combination of predictors that produced the most parsimonious model for each predictor variable. A "+" preceding a predictor indicates that the direction of relationship between that predictor and the response variable is positive, and "-" indicates that it is negative

${ }^{a}$ Indicates that a variable was $\ln (\mathrm{x}+1)$-transformed

${ }^{\mathrm{b}}$ Indicates that a variable was Arcsin $\sqrt{ }$-transformed

Bold value indicates a significant difference at $\alpha=0.05$

Models for kurper explained 51 and $57 \%$ of the total variation during spring and autumn respectively, and as for redfin, elevation was a top predictor of kurper density during both seasons. Elevation, negatively related to kurper density, explained a significant proportion of the variation in kurper density during both seasons (autumn: $P=0.002,39 \%$ variation; spring: $P=0.005,44 \%$ variation), and kurper densities were consistently higher at lower-lying sites. Maximum depth (correlated with mean depth) and canopy cover also featured in the models for kurper during spring and autumn respectively. During autumn, kurper densities were negatively related to depth $(P=0.029 ; 13 \%$ variation $)$, and positively related to canopy cover ( $P=0.044 ; 13 \%$ variation).

Trout density was negatively related to redfin and kurper densities, and was the only predictor included in the models for native fish during both early and late summer (Table 2), indicating a negative impact of trout on the densities of native fish during summer (Fig. 4b). Trout density explained a significant proportion of the variation in redfin and kurper density during both early (redfin: $P<0.001,66 \%$ variation; kurper: $P<0.016,26 \%$ variation) and late (redfin: $P<0.001,64 \%$ variation kurper: $P<0.002,43 \%$ variation) summer.

\section{Amandel River}

The models for redfin density during autumn, spring, early summer and late summer explained $42 \%$ and 33 ,
66 and $61 \%$ of the of the total variation in native fish densities respectively (Table 2). On the other hand, the models for kurper density during autumn, spring, early summer and late summer accounted for only 11 , 23,21 and $21 \%$ of the total variation respectively (Table 2), indicating a relatively large amount of unexplained variation in kurper density. Instream cover was the best predictor of redfin and kurper densities in both autumn and spring. Redfin and kurper densities were positively related to cover during both autumn (redfin: $P=0.025,17 \%$ variation; kurper: $P=0.056,20 \%$ variation), and spring (redfin: $P=0.006$, $42 \%$ variation; kurper: $P=0.049,23 \%$ variation), indicating that both species were consistently more abundant in habitats with a relatively high proportion of instream cover. The autumn model for redfin density also featured trout density and current velocity, and redfin were consistently more abundant at sites with relatively low trout densities and slow flows. In spring, the predictors temperature (Max_7), canopy cover, and current velocity featured alongside instream cover in the final model for redfin, and redfin tended to be more abundant at sites that remained relatively cool, had high canopy cover and low current velocity.

The model for redfin density in early summer included elevation $(P=0.042,22 \%$ variation $)$, maximum depth $(P=0.010,31 \%$ variation $)$ and trout density $(P=0.066,9 \%$ variation $)$, and redfin were more abundant at relatively deep sites with high elevations and low trout densities. Trout density, the 

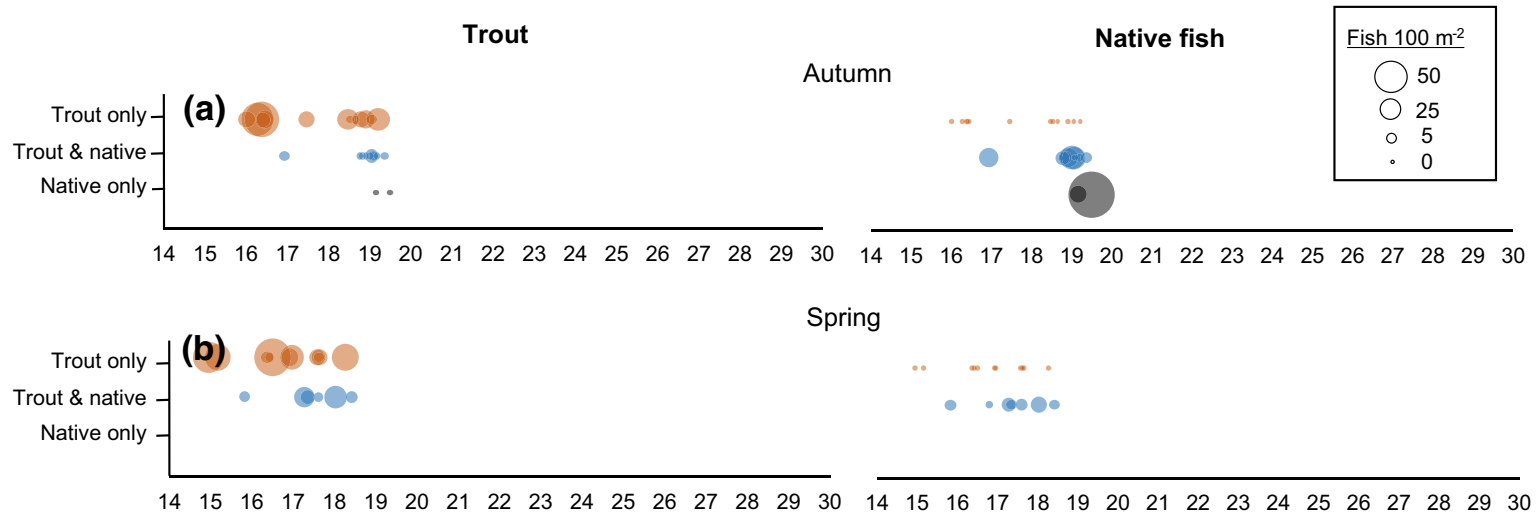

Early summer
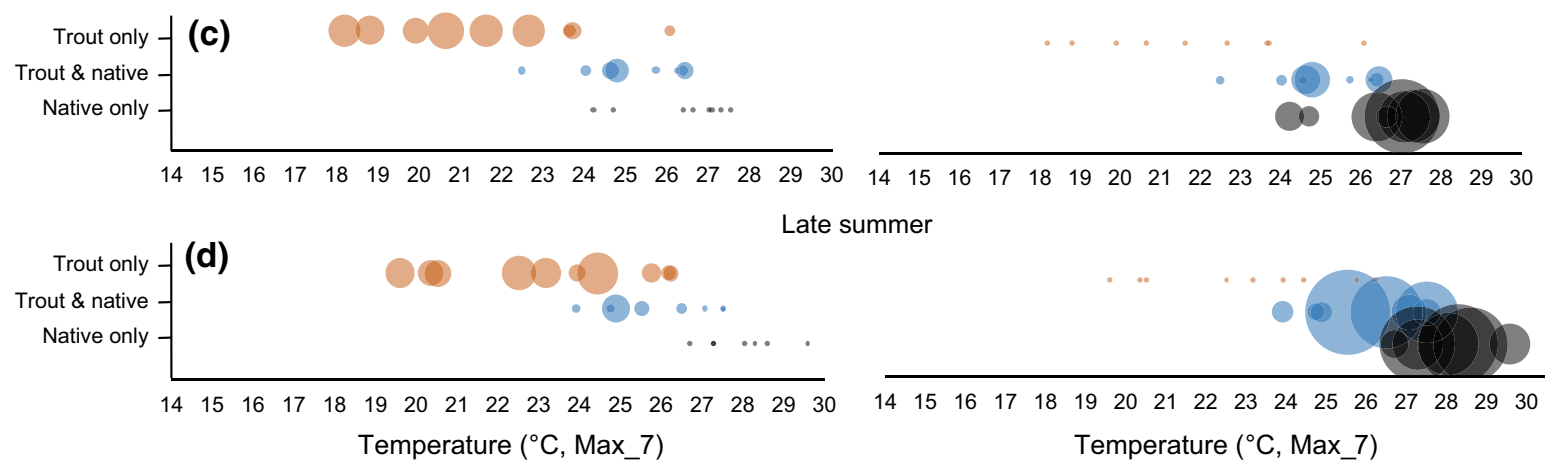

Fig. 5 Distribution of sites with trout only, trout and native fish together and native fish only along axes of maximum temperature (Max_7 over the month preceding fish sampling) during autumn, spring, early summer and late summer in the upper Berg River. Plots on the left represent the densities of trout, and plots on the right show the densities of native fish

only predictor included in the model for redfin density during late summer, was negatively, though not significantly, related to redfin density $(P=0.066$, $26 \%$ variation).

For kurper, current velocity featured in the autumn model alongside instream cover, and kurper density was negatively, though not significantly, related to current velocity, indicating that they were somewhat more abundant in habitats with relatively low flows. Dissolved oxygen (positively correlated with mean width and elevation) was the top predictor in the model for kurper density in early summer, followed by temperature (Max_7, and minimum temperature), and all three predictors explained a significant proportion in the variation in kurper density among sites (dissolved oxygen: $P=0.017,21 \%$ variation; Max_7: $P=0.041,18 \%$ variation; $\min : P=0.017$, $21 \%$ variation). Kurper densities were consistently (redfin, kurper and galaxias combined) at each site during each season. Bubble sizes are scaled to fish densities. Orange bubbles indicate sites with trout only, blue bubbles sites with both trout and native fish present and grey bubbles sites with native fish only

higher at warmer (high Max_7, low Min temperatures), low elevation sites with relatively low levels of dissolved oxygen and broad channel widths. Trout density was the only predictor included in the late summer model, but did not explain a significant proportion of the variation in kurper density among sites $(P=0.143,21 \%$ variation). Regardless, kurper density was consistently highest at sites with low trout densities, which is consistent with the pattern seen in the Berg River during summer.

Visualising patterns in fish assemblage structure and temperature

During autumn and spring (Fig. 5a, b), sites from the different fish categories did not separate out clearly along an axis of Max_7, and thermal heterogeneity among sites was relatively low. The highest trout 
densities were recorded at the sites with trout only during both seasons, and there were no sites with only native fish during the spring survey. In contrast, sites from the different fish assemblage groups separated out to some degree along the axis of Max_7 during the summer surveys (Fig. 5c, d). The sites with trout only were consistently associated with the lowest Max_7 values during both early $\left(18.2-26.1^{\circ} \mathrm{C}\right)$ and late $\left(19.6-26.2{ }^{\circ} \mathrm{C}\right)$ summer, and trout densities tended to be highest at these sites. Sites containing both trout and native fish were associated with intermediate Max_7 values during both early $\left(22.5-26.4{ }^{\circ} \mathrm{C}\right)$ and late $\left(23.9-27.5^{\circ} \mathrm{C}\right)$ summer, and trout densities were generally lower than at the trout only sites. Sites with native fish only were associated with the highest values of Max_7 for both early $\left(24.2-27.5^{\circ} \mathrm{C}\right)$ and late $\left(26.7-29.6^{\circ} \mathrm{C}\right)$ summer, and the highest native fish densities were recorded at these sites.

\section{Discussion}

Evaluating the susceptibility of aquatic species and habitats to the effects of climate warming and nonnative species is essential for effective conservation and management of freshwater systems (Rahel and Olden 2008; Jones et al. 2013). Our results from 51 sites in two CFE headwater streams over four seasons, support the hypothesis that water temperature is a key factor explaining spatio-temporal variation in the abundance of non-native rainbow trout, and the strength of associated impacts on native fish populations that inhabit these streams. Specifically, we show that temperature is a key predictor of trout density and distribution, and that a negative relationship exists between trout density and maximum water temperature during summer in both streams. Our data also support the hypothesis that temperature mediates the impact of trout on native fish abundance, in that the strongest impacts on native fish were observed where water temperature remains relatively low throughout the year (and trout density correspondingly high), and weaker impacts observed where relatively high temperatures occur during the warmer summer months (and trout density was correspondingly low, or trout were absent).

Estimates of the thermal requirements and limits of rainbow trout from studies in different geographic regions are variable, perhaps due to local adaptation
(Myrick and Cech 2004), variation in thermal history among river systems, differences in experimental protocols among studies (Chen et al. 2015) or differences in thermal metrics applied over different time scales. However, when consistent thermal metrics and temperature scenarios are used across broad geographic areas, it appears that trout thermal niches are conserved, and in the Rocky Mountains (U.S.), trout abundance consistently decreased where mean summer stream temperatures exceeded MWAT $18-22{ }^{\circ} \mathrm{C}$ (see Isaak et al. 2017). The negative relationship between trout and maximum temperature in summer in the CFE is broadly consistent with this pattern, in that trout densities decreased steadily at sites where summer temperatures exceeded $22{ }^{\circ} \mathrm{C}$ (Figs. 3, 4). We recorded trout at sites where summer Max_7 values (based on 1 month of preceding thermal data) reached $27.5^{\circ} \mathrm{C}$ in the Berg River and $27.1{ }^{\circ} \mathrm{C}$ in the Amandel River, but not at sites where Max_7 exceeded these values. Collectively our results indicate that while trout in CFE streams are negatively related to temperature, they can survive in habitats where Max_7 reaches $\sim 27{ }^{\circ} \mathrm{C}$, but not where the Max_7 is higher.

In South Africa, mean annual air temperatures are predicted to increase by $1.5-2.5^{\circ} \mathrm{C}$ along the coast and by $3.0-3.5^{\circ} \mathrm{C}$ in the far interior by the period 2046-2065 (Schulze 2011). Predicted increases in air temperature are likely to translate into increased stream temperatures, which may have severe consequences for stenothermic species like rainbow trout. As summer maximum stream temperatures rise, so will the proportion of CFE riverscape that exceeds a Max_7 of $27{ }^{\circ} \mathrm{C}$ during summer and essentially becomes unsuitable for rainbow trout. Already, 36\% of sites surveyed in the Berg River exceeded $27{ }^{\circ} \mathrm{C}$ Max_7 during late summer in 2016, and this percentage is expected to increase with climate warming.

Interestingly, many of the habitat patches that appear to function as thermal refugia for trout over summer exceed the chronic stress threshold for rainbow trout (Mean_7 $>18.2^{\circ} \mathrm{C}$ ). This suggests that fine scale thermal heterogeneity and refugia may enable trout to over-summer in such habitats. Indeed, the importance of thermal refugia resulting from groundwater seeps, thermal stratification in slowflowing deeper habitats and shading from the riparian zone or instream habitat features for trout during summer have been documented elsewhere. Ebersole 
et al. (2001) showed that trout in stream reaches in Oregon (USA) utilized thermal refugia resulting from groundwater seeps that were $3-8{ }^{\circ} \mathrm{C}$ colder than ambient stream temperatures that surpassed their upper thermal tolerance limits to survive over summer. The availability of thermal refugia created by groundwater seeps is expected to be negatively influenced by increased temperature, decreased rainfall and an associated drop in the water table (Frissell et al. 1996), which could potentially have negative consequences for trout in CFR streams if they rely on cold groundwater seeps to survive over summer. In the CFE, Dallas and Rivers-Moore (2011) documented significant fine-scale thermal variation among microhabitats in headwater streams, but the role of smallscale, cold-water refugia in enabling trout to persist over summer in the CFE remains to be studied.

Separating the influence of temperature from other habitat factors, both natural and human-related, is critical for accurately predicting changes in species distributions in response to climate warming (Buisson et al. 2008). Our study sites were in mountainous areas where human impacts are minimal, and our analyses considered a comprehensive suite of environmental parameters that, in addition to temperature, are known to influence fish distributions. Therefore, that maximum temperature emerged a top predictor in the summer models for trout density in both the Berg and Amandel Rivers highlights its importance in regulating trout density and distribution in these systems, and potentially other similar systems in the CFE. The inclusion of maximum depth and dissolved oxygen levels in models for trout during the summer surveys is consistent with the findings of Matthews and Berg (1997), and highlights the importance of deep, welloxygenated habitats for rainbow trout during summer in Californian stream pools.

Our results are broadly consistent with the findings of Ellender et al. (2016) who showed that trout distributions in the upper Keiskamma River system in the Eastern Cape of South Africa were limited at low elevations by high water temperatures, and that rainbow trout may become increasingly susceptible to localised extinctions if water temperatures increase. Similarly, a relationship between increasing water temperature and decreasing habitat availability for trout has been documented in the US (Isaak et al. 2010), and concern is growing that trout populations may be contracting into high-altitude cold water refugia (Flebbe et al. 2006; Jones et al. 2013). The best evidence for of range shifts or contractions comes from studies based on revisits to historical survey sites which have documented limited contractions at the warm-edge, and expansions at the cold-edge, of salmonid distributions (Eby et al. 2014; Al-Chokhachy et al. 2016). Headwater systems across the US may actually be more resilient to climate warming than previously thought because of annual snow melt and large, ongoing inputs of cold groundwater, and may thereby function as long-term cold water refugia habitats for native trout populations as the climate warms (Isaak et al. 2016).

Whether or not trout populations will be able to persist as CFE headwaters warm from downstream up is uncertain and could depend on the availability and accessibility of suitable habitats upstream of their present distribution. Habitat factors other than temperature like flow (expected to decrease due to reduced precipitation forecast for the CFE; Dallas and RiversMoore 2014), productivity, substrate composition and gradient in such reaches could also be important determinants of the suitability in upstream reaches for trout (Gibson-Reinemer et al. 2017). The trout populations in our study streams extend beyond our uppermost sites and future studies should examine upper distribution limits and habitat suitability in such reaches to better-understand whether these streams are likely to continue supporting trout in the future.

The strong negative relationship between trout and native fish densities in summer is consistent with the findings of Shelton et al. (2015) who documented a negative relationship between the density of trout and native CFE fish species. Since summer trout densities were best predicted by maximum temperature (negative relationship), our hypothesis that temperature mediates the impact of trout on native fish in CFE headwater streams is supported. Our data (Figs. 3, 5) suggest that sites which remain relatively cool (Max_7 $<27^{\circ} \mathrm{C}$ ) provide favourable habitat for trout over summer. Indeed, trout maintained relatively high densities $\left(>10\right.$ fish $100 / \mathrm{m}^{2}$ ) at such sites, and their corresponding high impact on native fish appears responsible for the absence of native fish at these sites. On the other hand, native fish co-occurred with trout at some of the sites that experienced higher Max_7 values during summer (Max_7: 22-28 ${ }^{\circ} \mathrm{C}$ ), presumably because such habitats are less optimal for trout resulting in lower densities and associated impacts on 
native fish. Then, the sites that experienced the highest summer temperatures (Max_7: 24-30 ${ }^{\circ} \mathrm{C}$ ) had no trout present at all, and also supported the highest native fish densities, presumably due to lack of trout predation.

These patterns indicate that trout distributions in these headwater streams expand during cooler seasons (autumn, spring) when thermal constraints are relaxed (maximum temperatures and thermal heterogeneity among habitats are relatively low), and that during such periods their impact on native fish may be relatively widespread and severe. Then, as maximum temperatures and thermal heterogeneity increase over summer, they contract into thermal refugia (habitat patches that remain relatively cool: Max_ $7<27^{\circ} \mathrm{C}$ ) leaving warmer habitats vacant to act as predation refugia for native fish over summer (Fig. 5).

Interestingly, the availability of predation refugia coincides with peak activity and spawning periods for the native species (Ellender et al. 2017), potentially allowing native fish abundances to replenish over the warm summer months. Populations therefore persist despite periods of high trout impacts during cooler times of year when trout distributions again expand and the proportion of trout and native fish in sympatry increases (Fig. 5). This hypothesis suggests that native fish may be better-adapted to high summer temperatures (Max_7 values up to $30{ }^{\circ} \mathrm{C}$; Fig. 5) than are trout, and that the warmest sites in these headwater streams may function as predation refugia for native fish during summer. The thermal tolerances of CFE native fishes should be further investigated in future studies.

In the Amandel River, native fishes appear to utilise a different kind of refuge from trout predation during cooler periods. During autumn and spring when trout distributions expand, native fish were concentrated in areas with relatively high proportions of instream cover. Presumably this is a behavioral response to avoid predation by trout, and similar responses to nonnative predators have been documented both locally (Shelton et al. 2008) and elsewhere (McDowall 2006). Instream cover (habitat complexity) may therefore be a key factor facilitating co-existence between trout and native fishes at times when temperature is not a limiting factor for trout, a subject for future research.

Although we considered a range of habitat parameters alongside trout in our analyses of factors explaining the observed fragmented native fish distributions, we cannot rule out the possibility that some of our sampling sites were historically devoid of native fish prior to trout invasion. For example, it is possible that the upper sites on the Berg River (sites B1-B7) where trout densities were consistently highest, and absence of native fish attributed to corresponding strong trout impacts, were never inhabited by native fishes at all because temperatures were too low, because of a physical dispersal dispersal barrier, or because of some other unmeasured habitat parameter. However, we could not identify a native fish distribution barrier and suspect that native fishes were indeed historically present at these sites because genera Pseudobarbus, Sandelia and Galaxias have been recorded where trout are absent in similar habitats, and at greater elevations (and presumably colder temperatures), in other CFE headwater streams (Shelton et al. 2015). In the Amandel River native fish were recorded at the upper-most sites (and observed several kilometres upstream of our study area), suggesting that historically they were likely present throughout the study reach, and indicating that trout impact is therefore the most plausible reason behind the observed fragmented native fish distribution patterns in that system.

Overall our findings contrast with the view of Rahel and Olden (2008) that climate change is expected to exacerbate non-native species impacts on native species; a pattern that typically holds true in the United States where introduced freshwater fishes generally tolerate higher temperatures than do native salmonids on which they prey, or with whom they compete for resources (Hitt et al. 2016). For example, temperature was identified as a key factor limiting the distribution of introduced smallmouth bass $M$. dolomieu, and associated impact on native Chinook salmon Oncorhynchus tshawytscha in the Pacific Northwest (US) (Lawrence et al. 2012). Thus, our finding that climate warming may have a positive spin-off for CFE native fishes at the expense of non-native trout was unexpected and may be unique to Mediterranean regions like South Africa where native species are better-adapted to relatively harsh and unpredictable aquatic environments. To our knowledge no other studies exist documenting a similar pattern for introduced rainbow trout.

In addition to rainbow trout, at least 15 other species of non-native freshwater fish have established in South Africa's CFE (Marr et al. 2012), and negative impacts of species like the sharptooth catfish and the 
black basses Micropterus spp. (both present downstream of our study reaches in both the Berg and Amandel Rivers) on native freshwater fishes have been documented (Ellender and Weyl 2014). Such species have higher thermal preferences than do trout, and could potentially invade warming headwater habitats with negative repercussions for remaining native fish populations. Thus, any habitat that native fish 'gain' the cold-edge of their distribution if trout populations contract upstream may be 'lost' at the warm-edge of their distribution if warm-adapted nonnatives encroach further upstream. Warm-adapted non-native fishes may therefore pose the greatest future threat to the value of headwater habitats as sanctuaries for native fishes, despite the fact that rainbow trout is presently the most common nonnative species in these habitats at present.

In conclusion, high temperatures appear to limit trout densities and distributions, and corresponding impact on small-bodied native fish populations during summer in headwater streams in the CFE-a novel pattern given that climate change is generally expected to exacerbate non-native species impacts on native species (Rahel and Olden 2008), and may have the unexpected outcome of benefiting threatened native fish populations in CFE headwater streams.

Acknowledgements This research was funded by the Water Research Commission (Grant K5_2337) and the Table Mountain Fund (Grant TM 2490) through grants awarded to the Freshwater Research Centre. OLFW and JMS acknowledge partial funding from the National Research Foundation-South African Research Chairs Initiative of the Department of Science and Technology (Inland Fisheries and Freshwater Ecology, Grant No. 110507) and the funding channelled through the NRF-SAIAB Institutional Support system. JMS acknowledges Stellenbosch University Subcommittee B, and the South African Institute for Aquatic Biodiversity (SAIAB) for financial support for this research. Any opinion, finding and conclusion or recommendation expressed in this material is that of the author(s) and the NRF does not accept any liability in this regard. For assistance in the field we thank Jenna Bowker, Jody Reizenberg, Chloe Wallace and Tumisho Ngobela, and for assistance with data processing we thank Toni Olsen.

\section{References}

Al-Chokhachy R, Schmetterling D, Clancy C, Saffel P, Kovach R, Nyce L, Liermann B, Fredenberg W, Pierceb R (2016) Are brown trout replacing or displacing bull trout populations in a changing climate? Can J Fish Aquat Sci 73:1395-1404. https://doi.org/10.1139/cjfas-2015-0293

Anderson MJ, Gorley RN, Clarke KR (2008) PERMANOVA + for PRIMER: guide to software and statistical methods. PRIMER-E, Albany

Brungs WA, Jones BR (1977) Temperature criteria for freshwater fish: protocol and procedures. US Environmental Protection Agency Environmental Research Laboratory, Duluth. EPA600/377061

Budaev SV (2010) Using principal components and factor analysis in animal behaviour research: caveats and guidelines. Ethology 116:472-480. https://doi.org/10.1111/j. 1439-0310.2010.01758.x

Buisson L, Grenouillet L (2009) Contrasted impacts of climate change on stream fish assemblages along an environmental gradient. Divers Distrib 15:613-626. https://doi.org/10. 1002/ece3.1539

Buisson L, Blanc L, Grenouillet G (2008) Modelling stream fish species distribution in a river network: the relative effects of temperature versus physical factors. Ecol Freshw Fish 17:244-257. https://doi.org/10.1111/j.1600-0633.2007. 00276.x

Burnham KP, Anderson DR (2002) Model selection and multimodel inference: a practical information-theoretic approach, 2nd edn. Springer, New York

Cassie D (2006) The thermal regime of rivers: a review. Freshw Biol 51:1389-1406. https://doi.org/10.1111/j.1365-2427. 2006.01597.x

Chakona A, Swartz ER (2012) Contrasting habitat associations of imperilled endemic stream fishes from a global biodiversity hotspot. BMC Ecol 12:19. https://doi.org/10.1186/ 1472-6785-12-19

Chen Z, Snow M, Lawrence GS, Church AR, Narum SR, Devlin RH, Farrell AP (2015) Selection for upper thermal tolerance in rainbow trout (Oncorhynchus mykiss Walbaum). J Exp Biol 218:803-812. https://doi.org/10.1242/jeb. 113993

Clark ME, Rose KA, Levine DA, Hargrove WW (2001) Predicting climate change effects on Appalachian trout: combining GIS and individual-based modeling. Ecol Appl 11:161-178

Clark BM, Impson ND, Rall J (2009) Present status and historical changes in the fish fauna of the Berg River, South Africa. Trans R Soc S Afr 64:142-163. https://doi.org/10. 1080/00359190909519249

Clarke KR, Gorley RN (2006) PRIMER v6: user manual/tutorial. PRIMER-E, Albany

Dallas HF (2008) Water temperature and riverine ecosystems: an overview of knowledge and approaches for assessing biotic responses, with special reference to South Africa. Water SA 34:393-404

Dallas HF, Rivers-Moore NA (2011) Micro-scale heterogeneity in water temperature. Water SA 37:505-512

Dallas HF, Rivers-Moore NA (2014) Ecological consequences of global climate change for freshwater ecosystems in South Africa. S Afr J Sci 110:1-11. https://doi.org/10. 1590/sajs.2014/20130274

de Moor FC, Day JA (2013) Aquatic biodiversity in the mediterranean region of South Africa. Hydrobiologia 719:237-268. https://doi.org/10.1007/s10750-013-1488-7 
Ebersole JL, Liss WJ, Frissell CA (2001) Relationship between stream temperature, thermal refugia and rainbow trout Oncorhynchus mykiss abundance in arid-land streams in the northwestern United States. Ecol Freshw Fish 10:1-10. https://doi.org/10.1034/j.1600-0633.2001.100101.x

Eby LA, Helmy O, Holsinger LM, Young MK (2014) Evidence of climate-induced range contractions in Bull trout Salvelinus confluentus in a Rocky Mountain Watershed, USA. PLoS ONE 9(6):e98812. https://doi.org/10.1371/ journal.pone.0098812

Ellender BR, Weyl OLF (2014) A review of current knowledge, risk and ecological impacts associated with non-native freshwater fish introductions in South Africa. Aquat Invasions 9:117-132. https://doi.org/10.3391/ai.2014.9.2.01

Ellender BR, Becker A, Weyl OLF, Swartz ER (2012) Underwater video analysis as a non-destructive alternative to electrofishing for sampling imperilled headwater stream fishes. Aquat Conserv Mar Freshw Ecosyst 22:58-65. https://doi.org/10.1002/aqc.1236

Ellender BR, Rivers-Moore NA, Coppinger CR, Bellingan TA, Weyl OLF (2016) Towards using thermal stress thresholds to predict salmonid invasion potential. Biol Invasions 18:513-3525. https://doi.org/10.1007/s10530-016-1244-9

Ellender BR, Wasserman RJ, Chakona A, Skelton PH, Weyl OLF (2017) A review of the biology and status of Cape Fold Ecoregion freshwater fishes. Aquat Conserv Mar Freshw Ecosyst 27:867-879. https://doi.org/10.1002/aqc. 2730

Fausch KD (2007) Introduction, establishment and effects of non-native salmonids: considering the risk of rainbow trout invasion in the United Kingdom. J Fish Biol 71:1-32. https://doi.org/10.1111/j.1095-8649.2007.01682.x

Fey SB, Herren CM (2014) Temperature-mediated biotic interactions influence enemy release of nonnative species in warming environments. Ecology 95:2246-2256. https:// doi.org/10.1890/13-1799.1

Flebbe PA, Roghair LD, Bruggink JL (2006) Spatial modeling to project southern Appalachian trout distribution in a warmer climate. Trans Am Fish Soc 135:1371-1382. https://doi.org/10.1577/T05-217.1

Frissell CA, Ebersole JL, Liss WJ, Cavallo BJ, Poole GC, Stanford JA (1996) Potential effects of climate change on thermal complexity and biotic integrity of streams: seasonal intrusion of non-native fishes. Environmental Protection Agency Final Report CR-822019-01-0. Duluth, Minnesota

Gibson-Reinemer DK, Rahel FJ, Albeke SE, Fitzpatrick RM (2017) Natural and anthropogenic barriers to climate tracking in river fishes along a mountain-plains transition zone. Divers Distrib 23:761-770. https://doi.org/10.1111/ ddi. 12576

Hitt N, Snook E, Massie D (2016) Brook trout use of thermal refugia and foraging habitat influenced by brown trout. Can J Fish Aquat Sci 74:406-418. https://doi.org/10.1139/ cjfas-2016-0255

Isaak DJ, Luce CH, Rieman BE, Nagel DE, Peterson EE, Horan DL et al (2010) Effects of climate change and wildfire on stream temperatures and salmonid thermal habitat in a mountain river network. Ecol Appl 20:1350-1371. https:// doi.org/10.1890/09-0822.1
Isaak et al (2016) Slow climate velocities of mountain streams portend their role as refugia for cold-water biodiversity. Proc Nat Acad Sci 113:4374-4379. https://doi.org/10. 1073/pnas. 1522429113

Isaak DJ, Wenger SJ, Young MK (2017) Big biology meets microclimatology: defining thermal niches of aquatic ectotherms at landscape scales for conservation planning. Ecol Appl 27:977-990. https://doi.org/10.1002/eap.1501

Jones LA, Muhlveld CC, Marshall LA, McGlynn BL, Kershner JL (2013) Estimating thermal regimes of bull trout and assessing the potential effects of climate warming on critical habitats. River Res Appl 30:204-216. https://doi.org/ 10.1002/rra.2638

Lawrence DJ, Olden JD, Torgerson CE (2012) Spatiotemporal patterns and habitat associations of smallmouth bass ( $\mathrm{Mi}$ cropterus dolomieu) invading salmon-rearing habitat. Freshw Biol 57:1929-1946. https://doi.org/10.1111/j. 1365-2427.2012.02847.x

Marr SM, Impson ND, Tweddle D (2012) An assessment of a proposal to eradicate non-native fish from priority rivers in the Cape Floristic Region, South Africa. Afr J Aquat Sci 37:131-142. https://doi.org/10.2989/16085914.2012. 666654

Matthews KR, Berg NH (1997) Rainbow trout responses to water temperature and dissolved oxygen stress in two southern California stream pools. J Fish Biol 50:50-67. https://doi.org/10.1111/j.1095-8649.1997.tb01339.x

McDowall RM (2006) Crying wolf, crying foul, or crying shame: alien salmonids and a biodiversity crisis in the southern cool-temperate galaxioid fishes? Rev Fish Biol Fish 16:233-422. https://doi.org/10.1007/s11160-0069017-7

McIntosh AR (2000) Habitat- and size-related variations in exotic trout impacts on native galaxiid fishes in New Zealand streams. Can J Fish Aquat Sci 57I:2140-2151. https://doi.org/10.1139/f00-188

Moyle PB, Kiernan JD, Crain PK, Quinones RM (2013) Climate change vulnerability of native and alien freshwater fishes of California: a systematic assessment approach. PLoS ONE 8:e63883. https://doi.org/10.1371/journal.pone. 0063883

Myrick CA, Cech JJ (2004) Temperature effects on juvenile anadromous salmonids in California's central valley: What don't we know? Rev Fish Biol Fish 14:113-123. https:// doi.org/10.1007/s11160-004-2739-5

Petty JT, Hansbarger JL, Huntsman BM, Mazik PM (2012) Brook trout movement in response to temperature, flow, and thermal refugia within a complex Appalachian riverscape. Trans Am Fish Soc 141:1060-1073. https://doi.org/ 10.1080/00028487.2012.681102

Rahel FJ, Olden JD (2008) Assessing the effects of climate change on aquatic invasive species. Conserv Biol 22:521-533. https://doi.org/10.1111/j.1523-1739.2008. 00950.x

Rivers-Moore NA, Dallas HF, Morris C (2013a) Towards setting environmental water temperature guidelines: a South African example. J Environ Manage 82:39-50. https://doi. org/10.1016/j.jenvman.2013.04.059

Rivers-Moore NA, Dallas HF, Ross-Gillespie V (2013b) Life history does matter in assessing potential ecological impacts of thermal changes on aquatic macroinvertebrates. 
River Res Appl 29:1100-1109. https://doi.org/10.1002/rra. 2600

Schulze RE (2011) A perspective on climate change and the South African water sector. Water Research Commission report 1843/2/11. Water Research Commission, South Africa

Shelton JM, Day JA, Griffiths CL (2008) Influence of largemouth bass, Micropterus salmoides, on abundance and habitat selection of Cape galaxias, Galaxias zebratus, in a mountain stream in the Cape Floristic Region, South Africa. Afr J Aquat Sci 33:201-210. https://doi.org/10. 2989/AJAS.2008.33.3.2.614

Shelton JM, Samways MJ, Day JA (2015) Predatory impact of non-native rainbow trout on endemic fish populations in headwater streams in the Cape Floristic Region of South Africa. Biol Invasion 17:365-379. https://doi.org/10.1007/ s10530-014-0735-9
Shelton JM, Weyl OLF, Chakona A, Ellender BR, Esler KJ, Impson ND, Jordaan MS, Marr SM, Ngobela T, Paxton BR, Van Der Walt JA (2017a) Vulnerability of Cape Fold Ecoregion freshwater fishes to climate change and other human impacts. Aquat Conserv Mar Freshw Ecosyst. https://doi.org/10.1002/aqc.2849

Shelton JM, Impson ND, Graham S, Esler KJ (2017b) Down, but not out: recent decline of Berg-Breede River whitefish (Barbus andrewi) in the upper Hex River. Koedoe. https:// doi.org/10.4102/koedoe.v59i1.1398

SPSS (2014) IBM SPSS statistics, version 22.0. SPSS Inc, Chicago

Woodward G, Perkins DM, Brown LE (2010) Climate change and freshwater ecosystems: impacts across multiple levels of organization. Philos Trans R Soc 365:2093-2106. https://doi.org/10.1098/rstb.2010.0055 